\title{
PELATIHAN PEMBUATAN BONEKA JARI BERGAMBAR DALAM MENINGKATKAN KEMAMPUAN MEMBACA ANAK USIA DINI DI KECAMATAN V KOTO KAMPUNG DALAM KABUPATEN PADANG PARIAMAN
}

\author{
Rakimahwati $^{1}$, Rivda Yetti², Syahrul Ismet ${ }^{3}$ \\ Jurusan PG PAUD, Fakultas Ilmu Pendidikan , Universitas Negeri Padang \\ Email : rakimahwati@gmail.com
}

\begin{abstract}
ABSTRAK
Tujuan dari pelatihan ini adalah untuk mengenalkan media pembelajaran pada guru yaitu (1) Menciptakan media pembelajaran membaca yang menyenangkan untuk anak; (2) Guru memiliki keterampilan dalam merancang boneka jari bergambar sebagai media pembelajaran membaca anak usia dini. Subjek pelatihan ini adalah anak Taman Kanak-kanak Melati Kecamatan V Koto Kampung Dalam Kabupaten Padang Pariaman. Sasaran dari pelatihan ini adalah guru-guru PAUD baik formal maupun nonformal se-Kecamatan V Koto Kampung Dalam Kabupaten Padang Pariaman. Adapun mitra dalam kegiatan ini adalah IGTKI Kecamatan V Koto Kampung Dalam Kabupaten Padang Pariaman. Pelaksanaan pelatihan adalah survei awal untuk mendata peserta pelatihan, mengurus surat izin untuk melaksanakan pelatihan, membuat buku panduan pelatihan, pelaksanaan pelatihan. Metode yang digunakan adalah praktek langsung. Metode praktek langsung digunakan agar peserta pelatihan mampu menciptakan boneka jari bergambar dalam meningkatkan kemampuan membaca anak. Hasil yang diperoleh guru dapat menciptakan boneka jari bergambar dengan empat tema untuk pengenalan membaca anak usia dini.
\end{abstract}

Kata Kunci: Anak Usia Dini, Boneka jari bergambar, Membaca

\begin{abstract}
The purpose of this training is to introduce learning media to teachers (1) Creating a fun learning media for children; (2) The teacher has the skills in designing pictorial finger puppets as a medium for early childhood reading learning. The subjects of this training were children of TK Melati in V Koto Kampung Dalam Kabupaten Padang Pariaman. The target of this training is PAUD teachers both formal and non-formal in V Koto Kampung Dalam Kabupaten Padang Pariaman. The partners in this activity were IGTKI Kampung Dalam Kabupaten Padang Pariaman. The training is an initial survey to record trainees, manage permits to carry out training, create training manuals, conduct training. The method used is direct practice. Direct practice methods are used so that trainees are able to create illustrated finger puppets in improving children's reading skills.the result obtained by the teacher can create illustrated finger puppets with four themes for early chilhood reading.
\end{abstract}

Keyword: early childhood, picture finger puppets, ability to read

\section{PENDAHULUAN}

Pendidikan merupakan sesuatu yang sangat penting, yang dibutuh semua anak. Pendidikan sebagai upaya untuk memajukan budi pekerti, pikiran serta jasmani anak, agar dapat memajukan kesempurnaan hidup dan menghidupkan anak yang selaras 
Rakimahwati, Rivda Yetti, Syahrul Ismet. PELATIHAN PEMBUATAN BONEKA JARI BERGAMBAR DALAM MENINGKATKAN KEMAMPUAN MEMBACA ANAK USIA DINI DI KECAMATAN V KOTO KAMPUNG DALAM KABUPATEN PADANG PARIAMAN. Early Childhood Vol. 2 No. 2b, November 2018

dengan alam dan masyarakat. Pendidikan dikelompokan kedalam pendidikan formal dan pendidikan non formal. Pendidikan formal sudah dapat diberikan kepada anak sejak anak berusia dini, bentuk pendidikan formal tersebut di namai dengan Pendidikan Anak Usia Dini. Undang-Undang No. 20 Tahun 2003 BAB I Pasal 1 ayat 14 tentang Sistem Pendidikan Nasional menyatakan bahwa pendidikan anak usia dini adalah upaya pembinaan yang ditujukan kepada anak sejak lahir sampai dengan usia enam tahun yang dilakukan melalui pemberian ransangan pendidikan untuk membantu pertumbuhan dan perkembangan jasmani dan rohani agar anak memiliki kesiapan memasuki pendidikan lebih lanjut.

Pendidikan anak usia dini jalur formal yaitu Taman Kanak-kanak. Taman Kanak-kanak yaitu pada anak yang berusia 4-6 tahun. Taman Kanakkanak membantu mempersiapkan anak dan memperkenalkan berbagai pengetahuan, sikap atau prilaku, dan keterampilan agar anak dapat melanjutkan kegiatan belajar yang sesungguhnya pada jenjang pendidikan selanjutnya. Tujuan dari Taman Kanakkanak menurut Kemendiknas (2010:3) adalah: 1)membangun landasan bagi berkembangnya potensi peserta didik agar menjadi manusia beriman dan bertaqwa kepada Tuhan Yang Maha Esa; berakhlak mulia, berkepribadian luhur, sehat, berilmu, cakap, kritis, kreatif, inovatif, mandiri, percaya diri dan menjadi warga Negara yang demokratis dan tanggung jawab; 2) mengembangkan potensi kecerdasan spritual, intelektual, emosional, kinestetik dan sosial peserta didik pada usia emas pertumbuhan dalam lingkungan bermain yang edukatif dan menyenangkan; 3) membantu peserta didik mengembangkan berbagai potensi baik psikis dan fisik yang meliputi nilainilai agama dan moral, sosialemosional, kemandirian, kognitif, bahasa, dan fisik/motorik untuk siap memasuki pendidikan dasar.

Salah satu aspek perkembangan yang penting untuk dikembangkan pada anak adalah perkembangan bahasa. Perkembangan bahasa merupakan bagian dari kemampuan yang harus dimiliki anak. Salah satu kemampuan berbahasa yang harus dikembangkan adalah kemampuan membaca, karena dengan membaca anak dapat memahami maksud dari kata dan kalimat, serta memahami bahwa ada 
Rakimahwati, Rivda Yetti, Syahrul Ismet. PELATIHAN PEMBUATAN BONEKA JARI BERGAMBAR DALAM MENINGKATKAN KEMAMPUAN MEMBACA ANAK USIA DINI DI KECAMATAN V KOTO KAMPUNG DALAM KABUPATEN PADANG PARIAMAN. Early Childhood Vol. 2 No. 2b, November 2018

hubungan antara bahasa lisan dengan tulisan. Hal ini sesuai dengan pendapat Ruddell dalam Aulina (2012) menyatakan bahwa membaca sebagai salah satu dari penggunaan berbahasa untuk menguraikan tulisan atau simbol dan memahaminya.

Kemampuan membaca anak usia Taman Kanak-kanak adalah kemampuan anak dalam mengubah simbol huruf ke dalam pengucapan atau lisan, kemampuan mengaitkan apa yang telah diucapkan anak dengan simbolnya dalam bentuk huruf. Anak secara mampu melakukan kombinasi bunyi, cara menuliskan atau merangkai hurufhuruf tersebut dan mampu membacanya. Anak mampu menguasai sintaksis (aturan kata/ kalimat) dan menguasai sematik (makna dari kata atau kata perkata yang dibacanya). Anak dikatakan mampu membaca sebuah kata atau kalimat singkat apabila anak tersebut mengerti dan mampu menyampaikan makna dari kata tersebut secara lisan. Hal ini sesuai dengan pandapat Hadini (2017) menyatakan bahwa kemampuan membaca merupakan kegiatan menelusuri, memahami, hingga mengeksplorasi berbagai simbol. Simbol dapat berupa rangkaian huruf-huruf dalam suatu tulisan atau bacaan bahkan gambar.

Mengingat begitu pentingnya mengembangkan kemampuan membaca anak, maka sebagai seorang guru harus dapat mengembangkan kemampuan membaca anak sejak dini. Kegiatan membaca pada anak usia Taman Kanakkanak dapat diberikan melalui berbagai media pembelajaran. Media pembelajaran yang didesain dengan bentuk dan warna yang menarik tentunya akan lebih efektif dalam mengembangkan kemampuan membaca anak karena anak memiliki daya ketertarikan yang tinggi terhadap sesuatu yang berwarna-warni. Anak akan lebih berhasil mempelajari sesuatu apabila yang dipelajarinya sesuai dengan minat, kebutuhan dan kemampuannya. Apabila anak belajar membaca dengan media yang menarik secara visual, yang disajikan sesuai dengan metode membaca yang tepat untuk anak dan dilakukan secara konsisten, berkesinambungan, dalam suasana menyenangkan dan kondusif, maka potensi-potensi yang dimiliki oleh anak akan berkembang dengan baik.

Kurangnya kemampuan anak dalam kegiatan membaca terlihat dari 
Rakimahwati, Rivda Yetti, Syahrul Ismet. PELATIHAN PEMBUATAN BONEKA JARI BERGAMBAR DALAM MENINGKATKAN KEMAMPUAN MEMBACA ANAK USIA DINI DI KECAMATAN V KOTO KAMPUNG DALAM KABUPATEN PADANG PARIAMAN. Early Childhood Vol. 2 No. 2b, November 2018

anak masih kesulitan saat menyebutkan huruf-huruf, menyebutkan huruf awal yang terlihat, menghubungkan gambar dengan kata. Hal ini di sebabkan karena guru hanya menggunakan media yang terbatas dengan menggunakan papan tulis, majalah, lembar kerja anak, dan kartu huruf yang tidak mencukupi seluruh anak, kurangnya kemampuan guru menciptakan permainan yang menarik untuk mengembangkan kemampuan membaca anak. Kondisi ini yang menjadi pendorong bagi penulis untuk melakukan kegiatan pelatihan ini. Selain kondisi umum sebagaimana yang dikemukakan diatas, usulan program PKM ini disusun berdasarkan kondisi mitra saat ini, sesuai dengan informasi pada observasi awal yang dilakukan. Tujuan dilakukan pelatihan ini yaitu meningkatkan keterampilan guru dalam menciptakan media pembelajaran dan keterampilan dalam merancang boneka jari bergambar sebagai media pembelajaran membaca anak usia dini.

Para ahli memiliki definisi yang berbeda tentang membaca. Sutan dalam Suryana (2016:127) membaca dapat diartikan sebagai kegiatan menelusuri, memahami hingga mengeksplorasikan sebagai simbol. Simbol dapat berupa rangkaian huruf-huruf dalam suatu tulisan atau bacaan bahkan gambar (denah, grafik, dan peta).

Hartati dalam Susanto (2011:84) membaca anak usia dini merupakan kegiatan fisik dan mental untuk menemukan makna dari tulisan serta mengenal huruf-huruf. Membaca dikatakan sebagai kegiatan fisik karena pada saat membaca bagian-bagian tubuh khususnya mata membantu melakukan proses membaca. Membaca juga dikatakan sebagai kegiatan mental karena pada saat membaca bagianbagian pikiran khususnya persepsi dan ingatan terlibat di dalamnya. Berdasarkan pendapat para ahli diatas dapat disimpulkan membaca anak usia dini adalah suatu kegiatan yang melibatkan unsur auditi dan visual serta kemampuan dalam mengingat simbolsimbol yang berbentuk huruf dalam rangkaian kata yang mengandung makna. Kemampuan membaca termasuk kegiatan yang komplek dan melibatkan berbagai keterampilan.

Menurut Steinberg dalam Susanto (2011:90-91) mengatakan bahwa, kemampuan membaca anak usia dini dapat dibagi atas empat tahap perkembangan, yaitu: 1) Tahap timbulnya kesadaran terhadap tulisan; 2) Tahap membaca gambar; 3) Tahap 
Rakimahwati, Rivda Yetti, Syahrul Ismet. PELATIHAN PEMBUATAN BONEKA JARI BERGAMBAR DALAM MENINGKATKAN KEMAMPUAN MEMBACA ANAK USIA DINI DI KECAMATAN V KOTO KAMPUNG DALAM KABUPATEN PADANG PARIAMAN. Early Childhood Vol. 2 No. 2b, November 2018

pengenalan bacaan; 4) Tahap membaca lancar.

Menurut Bromley dalam Suryana (2016:130) kemampuan membaca pada anak berlangsung dalam beberapa tahap yaitu 1) Tahap fantasi; 2) Tahap pembentukan konsep diri; 3) Tahap membaca gambar; 4) Tahap pengenalan bacaan; 5) Tahap membaca lancar. Berdasarkan pendapat diatas disimpulkan bahwa Tahap perkembangan kemampuan membaca anak usia dini secara umum adalah Tahap timbulnya kesadaran terhadap tulisan atau fantasi, tahap pembentukan konsep diri, tahap membaca gambar, tahap pengenalan bacaan,dan tahap membaca lancar.

Menurut Steinberg dalam susanto (2011:83) membaca dini atau awal adalah membaca yang diajarkan secara terprogram kepada anak prasekolah. Program ini menumpukkan perhatian pada perkataan-perkataan utuh, bermakna dalam konteks pribadi anakanak dan bahan-bahan yang diberikan melalui permainan dan kegiatan yang menarik sebagai perantara pembelajaran. Menurut Brata dalam Kumara (2014:1) mengungkapkan bahwa pembelajaran membaca tingkat permulaan merupakan tingkatan proses pembelajaran membaca untuk menguasai sistem tulisan sebagai representasi visual bahasa.

Berdasarkan pendapat para ahli tersebut, dapat disimpulakan bahwa membaca dini atau awal atau permulaan merupakan proses kegiatan pembelajaran yang terpadu seperti memberikan pengetahuan mengenal huruf-huruf, kata-kata serta menghubungkan rangkaian huruf tersebut dengan bunyi dan maknanya yang dikemas dalam kegiatan yang menarik bagi anak.

Kustandi dan Sutjipto (2011:9) berpendapat, media pembelajaran adalah alat yang dapat membantu proses belajar mengajar dan befungsi untuk memperjelas makna pesan yang disampaikan, sehingga dapat mencapai tujuan pembelajaran dengan baik dan sempurna. Degeng dalam Trianto (2016:227) media pembelajaran adalah komponen strategi penyampaian yang dapat dimuati pesan yang akan disampaikan kepada si belajar, apakah itu orang, alat, atau bahan.

Berdasarkan pendapat para ahli diatas dapat disimpulkan bahwa media pembelajaran adalah suatu alat yang 
Rakimahwati, Rivda Yetti, Syahrul Ismet. PELATIHAN PEMBUATAN BONEKA JARI BERGAMBAR DALAM MENINGKATKAN KEMAMPUAN MEMBACA ANAK USIA DINI DI KECAMATAN V KOTO KAMPUNG DALAM KABUPATEN PADANG PARIAMAN. Early Childhood Vol. 2 No. 2b, November 2018

digunakan untuk membantu proses belajar mengajar atau sebagai alat perantara dalam proses pembelajaran yang bertujuan untuk mencapai tujuan yang diinginkan. Media pembelajaran digunakan untuk merangsang pikiran, perasaan, perhatian dan kemampuan atau keterampilan belajar.

Penggunaan boneka jari bergambar dapat dimanfaatkan sebagai media pembelajaran dalam meningkatkan kemampuan membaca anak. Sejalan dengan Eliyawati (2005:71) menyatakan bahwa boneka jari bergambar bertujuan untuk mengembangkan bahasa anak, mempertinggi keterampilan dan kreatifitas anak, belajar bersosialisasi dan bergontong royong, serta melatih keterampilan jari jemari tangan.

Boneka jari bergambar dapat menarik perhatian anak dan merangsang aktifitas anak sehingga anak tidak merasa bosan, terpaksa, serta mampu meningkatkan kemampuan membaca anak. Sejalan dengan Kamtini (2005:61) boneka jari bergambar adalah alat permainan yang mampu merangsang dan menarik minat anak, sekaligus mampu mengembangkan berbagai jenis kemampuan anak dan tidak hanya pada satu aktifitas tertentu saja.
Boneka jari bergambar tidak hanya digunakan dalam meningkat kemampuan membaca saja tetapi juga dapat digunakan untuk meningkatkan potensi-potensi lain pada anak serta boneka jari bergambar sangat mudah di gunakan baik bagi guru maupun anak. Menurut Purwaty (2011:4) keuntungan penggunaan boneka jari bergambar adalah 1) tidak memerlukan banyak tempat, waktu yang banyak, biaya dan persiapan yang tidak terlalu rumit; 2) tidak menuntut keterampilan yang rumit bagi yang akan memainkan; 3) dapat mengembangkan imajinasi anak, mempertinggi kreatifitas dan menambah suasana gembira; 4) dapat menarik minat anak dalam membaca huruf.

Tujuan dilakukan pelatihan ini yaitu meningkatkan keterampilan guru dalam menciptakan media pembelajaran dan keterampilan dalam merancang boneka jari bergambar sebagai media pembelajaran membaca anak usia dini.

\section{METODE PENELITIAN}

Berdasarkan permasalahan yang ditemukan mitra PKM yang telah diuraikan sebelumnya, maka metode yang ditawarkan untuk menyelesaikan permasalahan rendahnya keterampilan dan kesadaran guru TK/RA di 
Rakimahwati, Rivda Yetti, Syahrul Ismet. PELATIHAN PEMBUATAN BONEKA JARI BERGAMBAR DALAM MENINGKATKAN KEMAMPUAN MEMBACA ANAK USIA DINI DI KECAMATAN V KOTO KAMPUNG DALAM KABUPATEN PADANG PARIAMAN. Early Childhood Vol. 2 No. 2b, November 2018

Kecamatan V Koto Kampung Dalam

Padang

Pariaman

dalam

mengembangkan kemampuan membaca anak usia dini dengan media boneka jari bergambar dan telah disepakati bersama mitra yang dipilih sebagai sampel yaitu TK Melati V Koto Kampung Dalam Padang Pariaman.

Metode pelatihan pembuatan boneka jari bergambar dalam meningkatkan kemampuan membaca anak usia dini di kecamatan $\mathrm{V}$ Koto Kampung Dalam Kabupaten Padang Pariaman melalui beberapa tahap:

1. Membuat buku pedoman pelatihan mengembangkan kemampuan membaca menggunakan boneka jari bergambar untuk guru-guru TK di kecamatan V Koto Kampung Dalam Kabupaten Padang Pariaman yang berisi konsepkonsep antara lain 1) pengenalan konsep membaca; 2) penggunaan boneka jari bergambar sebagai media pengembangan kemampuan membaca; 3) alat dan bahan pembuatan boneka jari bergambar; 4) proses pembuatan boneka jari bergambar; 5) langkah-langkah permainan boneka jari bergambar;
6) praktek permainan boneka jari bergambar.

2. Melakukan sosialisasi dan pelatihan permainan boneka jari bergambar yang ditujukan bagi guru-guru TK di kecamatan V Koto Kampung Dalam Kabupaten Padang Pariaman melibatkan 30 orang peserta. Pelatihan pertama bersifat sosialisasi pemahaman materi tentang konsep kemampuan membaca anak usia dini menggunakan boneka jari bergambar, pelatihan kedua yaitu praktek langsung pembuatan boneka jari bergambar sebagai media dalam mengembangkan kemampuan membaca anak usia dini.

3. Latihan langsung secara mandiri dengan memanfaatkan pembuatan boneka jari bergambar untuk mengembangkan kemampuan membaca anak usia dini.

\section{HASIL DAN PEMBAHASAN}

Pelatihan pembuatan boneka jari bergambar dalam meningkatkan kemampuan membaca anak usia dini yang ditujukan bagi guru-guru di kecamatan V Koto Kampung Dalam Kabupaten Padang Pariaman di TK 
Rakimahwati, Rivda Yetti, Syahrul Ismet. PELATIHAN PEMBUATAN BONEKA JARI BERGAMBAR DALAM MENINGKATKAN KEMAMPUAN MEMBACA ANAK USIA DINI DI KECAMATAN V KOTO KAMPUNG DALAM KABUPATEN PADANG PARIAMAN. Early Childhood Vol. 2 No. 2b, November 2018

Melati kecamatan V Koto Kampung

Dalam Kabupaten Padang Pariaman.



Gambar 1. TK Melati V Koto Kampung

Dalam Padang Pariaman

Kegiatan Pelatihan pembuatan boneka jari bergambar dalam meningkatkan kemampuan membaca anak usia dini yang ditujukan bagi guruguru di kecamatan V Koto Kampung Dalam Kabupaten Padang Pariaman. Narasumber menjelaskan tentang penggunaan boneka jari bergambar dalam mengembangkan kemampuan membaca anak serta mengenalkan bahan dan pembuatan boneka jari bergambar kepada guru-guru.

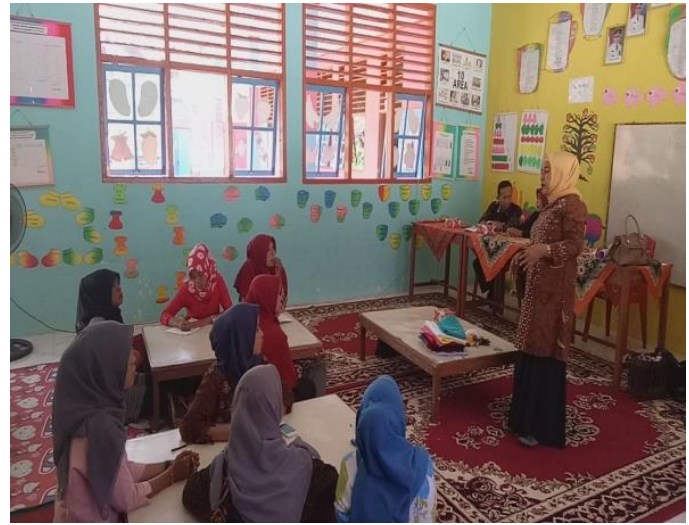

Gambar 2. Narasumber menyajikan Gambar 2. Narasumber menyajikan

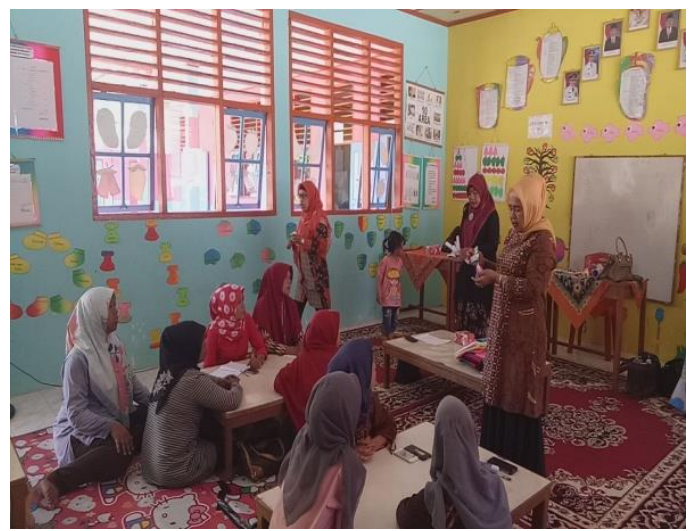

Gambar 3. Narasumber menjelaskan materi kepada guru-guru.

Narasumber dan peserta menentukan tema. Peserta dibagi menjadi 4 kelompok, masing-masing kelompok mendapat satu sub tema yaitu tanaman buah, tanaman hias, tanaman obat-obatan, dan tanaman perdu. Kelompok melakukan proses pembuatan boneka jari bergambar berdasarkan sub tema yang didapatnya. 


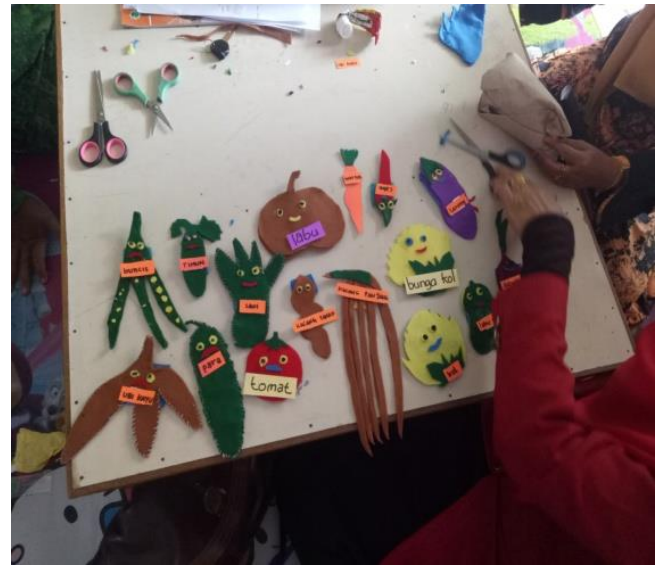

Gambar 4.Hasil boneka jari bergambar Setelah pembuatan boneka jari bergambar selesai, masing-masing kelompok mencobakan langsung penggunaan boneka jari dalam mengembangkan kemampuan membaca anak serta di dampingi oleh narasumber, narasumber memberikan saran ketika penampilan kelompok selesai untuk memperbaiki dan menyempurnakan penampilan peserta penggunakan boneka jari bergambar dalam mengembangkan kemampuan membaca anak.

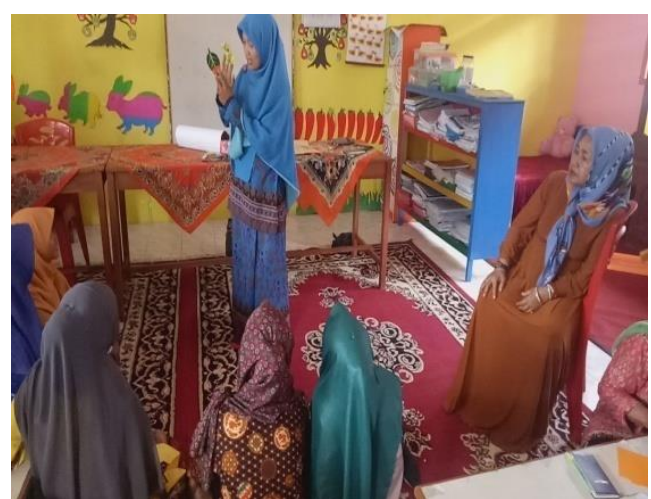

Gambar 5. Kelompok mencobakan

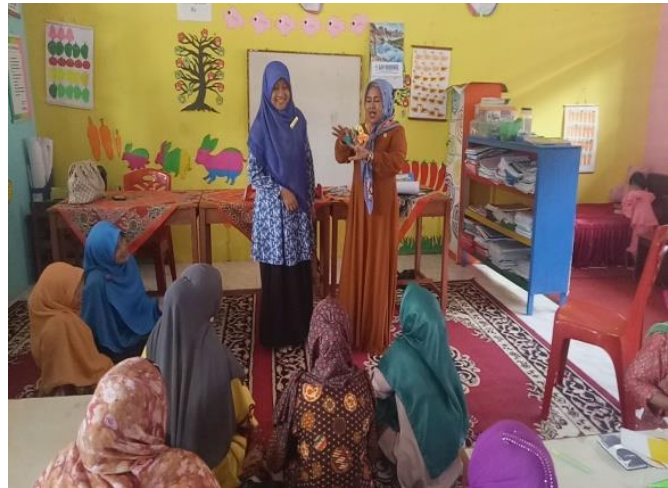

Gambar 6.Narasumber memberikan Penjelasan

Pelatihan pembuatan boneka jari bergambar memperoleh hasil yang memuaskan berdasar hasil akhir produk yang di buat oleh guru-guru kecamatan V Koto Kampung Dalam Kabupaten Padang Pariaman. Guru mampu menciptakan boneka jari bergambar sesuai dengan sub tema yang ditentukan dengan bentuk yang menarik dan warna yang menarik dalam mengembangkan kemampuan membaca anak. Apabila seorang guru mampu menciptakan media pembelajaran yang menarik maka dapat membantu proses pembelajaran dan menciptakan wadah yang baik untuk mengembangkan potensi-potensi anak. Sejalan dengan pendapat Kustandi dan Sutjipto (2011:9) berpendapat, media pembelajaran adalah alat yang dapat membantu proses belajar mengajar dan befungsi untuk memperjelas makna 
Rakimahwati, Rivda Yetti, Syahrul Ismet. PELATIHAN PEMBUATAN BONEKA JARI BERGAMBAR DALAM MENINGKATKAN KEMAMPUAN MEMBACA ANAK USIA DINI DI KECAMATAN V KOTO KAMPUNG DALAM KABUPATEN PADANG PARIAMAN. Early Childhood Vol. 2 No. 2b, November 2018

pesan yang disampaikan, sehingga dapat mencapai tujuan pembelajaran dengan baik dan sempurna.

\section{SIMPULAN}

Berdasarkan hasil evaluasi akhir untuk mengukur ketercapaian tujuan program kegiatan pelatihan pembuatan boneka jari bergambar dalam meningkatkan kemampuan membaca anak usia dini, yang ditujukan bagi guru-guru di kecamatan V Koto Kampung Dalam Kabupaten Padang Pariaman di TK Melati kecamatan V Koto Kampung Dalam Kabupaten Padang Pariaman, melalui hasil tes akhir dan observasi kualitas produk yang dihasilkan yaitu dapat meningkatkan keterampilan guru dalam merancang boneka jari bergambar sebagai media pembelajaran membaca anak usia dini.

\section{DAFTAR PUSTAKA}

Aulina, Choirun Nisak. 2012. Pengaruh Permainan dan Penguasaan Kosakata terhadap Kemampuan Membaca Permulaan Anak Usia 5-6 tahun. Jurnal Pedagogia. Vol. 1, No. 2.

Departemen Pendidikan Nasional. 2003. Pengembangan Model Pembelajaran di Taman
Kanak-kanak, Direktorat

Pembinaan Taman Kanakkanak dan Sekolah Dasar. Jakarta: Depdiknas.

Eliyawati, Cucu. 2005. Pemilihan Pengembangan Sumber Belajar Unruk Anak Usia Dini. Jakarta: Depdiknas.

Hadini, Nining. 2017. Meningkatkan Kemampuan Membaca Anak Usia Dini melalui Kegiatan Permainan Kartu Kata di TK Al-Fauzan Desa Ciharashas Kecamatan Cilaku Kabupaten Cianjur. Journal Empowerment. Vol. 6, No. 1 Februari 2017, ISSN No, 22524738.

Kamtini. 2005. Bermain Melalui Gerak dan Lagu di Taman Kanakkanak. Jakarta: Depdiknas.

Kumara, Amitya. dkk. 2014.Kesulitan Berbahasa Pada Anak. Yogyakarta: PT Kanisius.

Kustandi, Cecep dan Bambang Sutjipto. 2011. Media Pembelajaran Manual dan Digital. Bogor: Ghalia Indonesia.

Suryana, Dadan. 2016. Pendidikan Anak Usia Dini (Stimulasi \& Aspek Perkembangan Anak). Jakarta: Kencana. 
Rakimahwati, Rivda Yetti, Syahrul Ismet. PELATIHAN PEMBUATAN BONEKA JARI BERGAMBAR DALAM MENINGKATKAN KEMAMPUAN MEMBACA ANAK USIA DINI DI KECAMATAN V KOTO KAMPUNG DALAM KABUPATEN PADANG PARIAMAN. Early Childhood Vol. 2 No. 2b, November 2018

Susanto, Ahmad. 2011. Perkembangan Anak Usia Dini: Pengantar Dalam Berbagai Aspeknya. Jakarta: Kencana Pranada Media Group.

Trianto. 2016. Desain pengembangan pembelajaran tematik bagi anak usia dini TK/RA \& Anak Usia kelas awal SD/MI. Jakarta: Kencana. 